\title{
Формирование столичных функций Москвы в планировочной структуре города с 1918 по 2018 год
}

\author{
Ю.П.Бочаров, ЦНИИП Минстроя, Москва \\ С.Б.Ткаченко, МАРХИ, Москва
}

Вопрос о формировании столичного административно-политического центра возник в 1918 году после переезда советского правительства в Москву. Стратегия размещения зданий высших органов государственной власти эволюционировала вместе с пониманием миссии и роли законодательной, исполнительной и судебной ветвей власти в советское время и после 1991 года. Советская политико-правовая доктрина отвергала принцип разделения властей как буржуазный и неприемлемый для социалистического общества, поэтому здания, где работали исполнительная и законодательная власть, находились в Кремле. Проекты Дворца советов закрепляли этот принцип. Дворец советов как символ победы советского строя претендовал стать самым высоким, амбициозным зданием своего времени. Конституциональное изменение структуры ветвей власти в начале 1990-х годов, после которого появились новые высшие органы государства: Совет Федерации, Государственная Дума, Правительство и судебные органы Российской Федерации, - не привело к принципиальному изменению градостроительной политики в отношении размещения зданий власти, которые занимали приспособлявшиеся для этого объекты. Концепции размещения нового федерального правительственного центра, появлявшиеся с 1996 года, не нашли отражения в части 4 Генерального плана развития Москвы до 2025 года: «Обеспечение интересов Российской Федерации в развитии столицы Российской Федерации - города федерального значения Москвы». Инаугурация президента отражает приспособленность общественных пространств, формируемых ансамблями зданий государственной власти, к выполнению столицей государства своих столичных функций. Полицентрический принцип формирования градостроительной структуры соответствует демократической структуре общества и власти. Пространственное разделение равнозначных комплексов зданий законодательной, исполнительной и судебной власти создаёт масштаб, соответствующий парадигме столичности, и символизирует взаимную независимость государственных функций.

Ключевые слова: столичные функции, законодательная, исполнительная и судебная ветви власти, планировочная структура Москвы.

Formation of the Capital Functions of Moscow in the City Planning Structure from 1918 to 2018

Yu.P.Bocharov, RAACS, Moscow

S.B.Tkachenko, MARKHI, Moscow

The question of the formation of the Moscow administrativepolitical center arose in 1918 after the Soviet government moved to Moscow. The strategy of placing the buildings of the highest bodies of state power has evolved along with an understanding of the mission and role of the legislative, executive and judicial branches in Soviet times and after 1991. The Soviet political and legal doctrine rejected the principle of separation of powers as bourgeois and unacceptable to socialist society, therefore the buildings where the executive andlegislative powers worked were in the Kremlin. The projects of the Palace of Soviets reinforced this principle. The Palace of Soviets, as a symbol of the victory of the Soviet system, claimed to be the tallest, most ambitious building of its time. The constitutional change in the structure of the branches of government in the early 1990s, after which new state supreme bodies appeared: the Federation Council, the State Duma, the Government and the judiciary of the Russian Federation, did not lead to a fundamental change in the urban planning policy regarding the location of the buildings for such bodies. The concept of the location of the new federal government center, appeared since 1996, was not reflected in part 4 of the General Development Plan of Moscow until 2025: “Ensuring the interests of the Russian Federation in the development of the capital of the Russian Federation - Moscow, the city of federal importance". The inauguration of the president reflects the adaptability of public spaces, formed by ensembles of buildings of the state authorities, to the performance of the capital functions by the capital of the state. The polycentric principle of forming a city planning structure is consistent with the democratic structure of society and its government. The spatial separation of equivalent building complexes of legislative, executive and judicial authorities creates a scale corresponding to the paradigm of the capital of the state, and symbolizes the mutual independence of state functions.

Keywords: capital functions, legislative, executive and judicial branches of government, planning structure of Moscow

В XX веке в России дважды сменилась социально-политическая формация. В октябре 1917 года Российская империя превратилась в РСФСР, а затем, в 1922 году, в СССР. Первые пять месяцев столицей РСФСР оставался Петроград, 12 марта 1918 года правительство переехало в Москву. Тогда Москва вернула себе статус столичного города, утраченный в начале XVIII века.

Перенос столицы в Москву в 1918 году трактовался как временная мера, «впредь до изменения» сложившейся внешне- и 
внутриполитической ситуации [1]. Из трёх рассматриваемых вариантов размещения правительства Л. Троцким по соображениям безопасности был выбран Кремль. Через четыре года, 30 декабря 1922 года, Первый Всесоюзный съезд Советов провозгласил Москву столицей СССР, и Кремль стал постоянным местом размещения законодательной и исполнительной власти (рис. 1).

Проекты планировки и реконструкции новой, социалистической Москвы, стали появляться сразу после переезда советского правительства из Петрограда (рис. 2). В это время Москва позиционировалась новой властью как столица мировой революции. С 1922 году, после образования СССР, этот лозунг сохранился, но подвергся уточнению: столица первого в мире социалистического государства.

Новая столица должна была иметь новые столичные учреждения, поскольку Кремль и те здания, в которых располагались наркоматы и Советы рабочих, крестьянских и солдатских депутатов, достались от прежней власти. Простого уничтожения на фасадах символики Российской империи было недостаточно. После завершения второго этапа Граж-

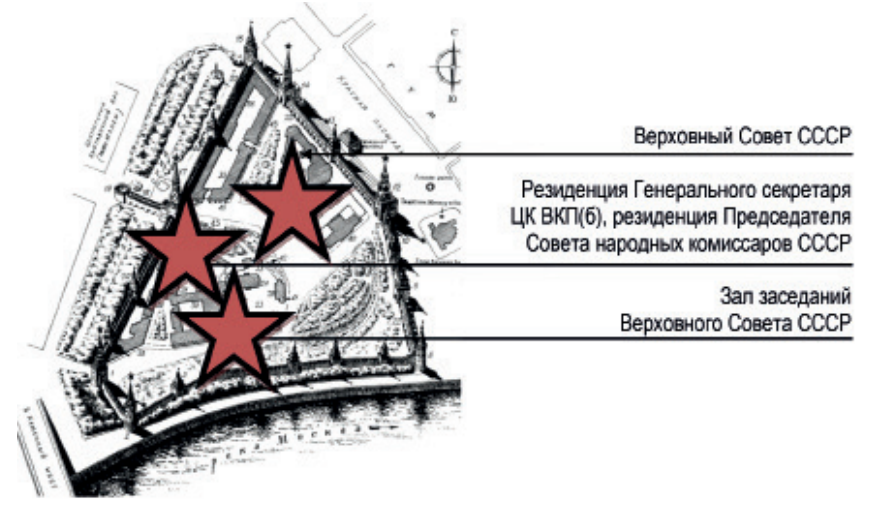

Рис. 1. Московский Кремль - резиденция обеих ветвей советской власти

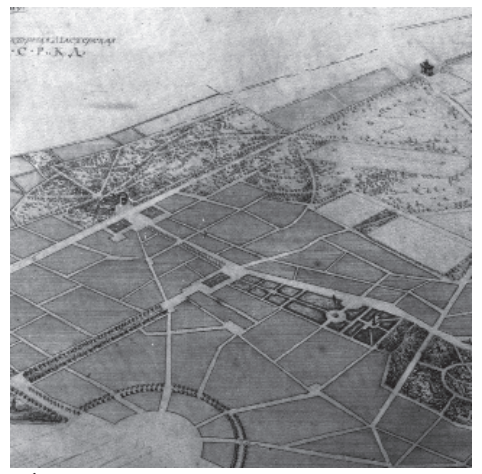

a)

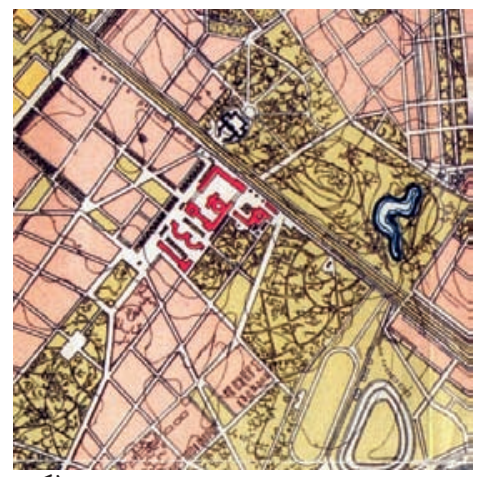

б)

данской войны (1918-1920), когда из страны ушли войска интервентов и произошёл коренной перелом в ходе военных действий, советское правительство стало чувствовать себя уверенно, взяв под контроль основную территорию страны. В это время встал вопрос о формировании в Москве административно-политического центра.

Послереволюционные проекты перепланировки Москвы по-разному отвечали на этот вызов времени. По плану «Новая Москва» Кремль преобразовывался в музей, функция общественного центра разделялась между Кремлем (рис. 3 в) и окружавшими его местными административными центрами, а также новым административно-политическим центром СССР на Петроградском шоссе - с Екатерининским путевым дворцом и Ходынским полем (рис. 3 а, б). Вынос столичных функций из исторического ядра города на его периферию не нашёл понимания у советской власти, и Ходынское поле осталось аэродромом.

Идеологическим ядром исторического административного центра Москвы, намеченным планом «Новая Москва», должен был стать Дворец труда в Охотном Ряду (рис. 3 г). Это был пер-
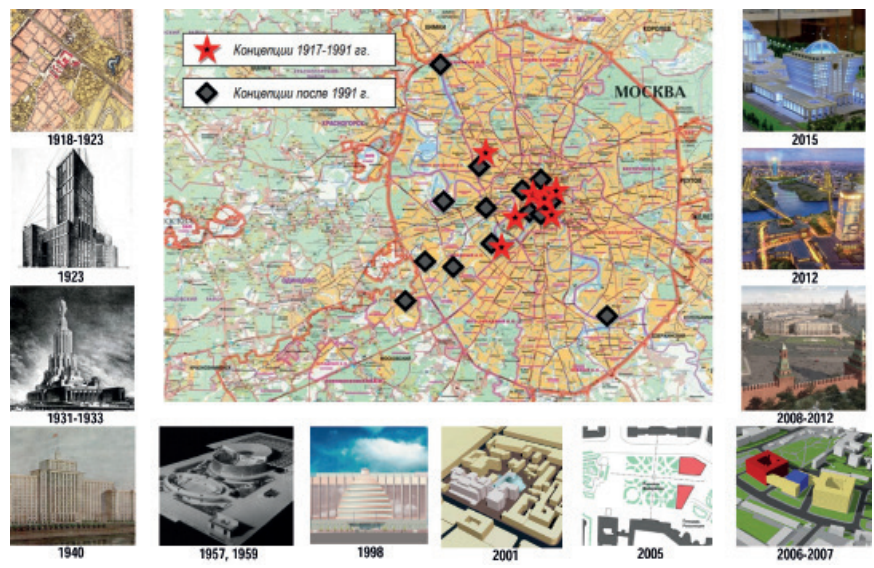

Рис. 2. Архитектурные и градостроительные концепции размещения высших органов государственной власти на карте Москвы

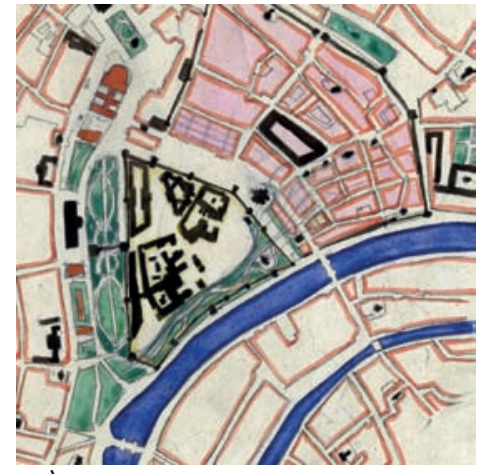

в)

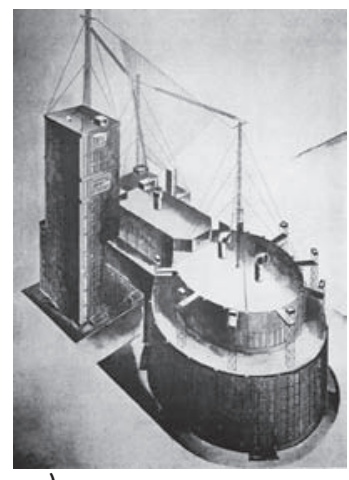

2)

Рис. 3. Проекты высших органов власти на революционно-романтическом этапе московского градостроительства (19171928): а) 1920 год. Перспективный вид Ходынского поля с административно-политическим центром СССР. Архитектурная мастерская МСРиКД. Мастера-архитекторы: И. Фидлер, К. Мельников, А. Поляков (из архива А.В. Щусева); б) 1923 год. Фрагмент плана «Новой Москвы» с административно-политическим центром (сСР на Ходынском поле; в) 1922 год. Эскиз к плану «Новой Москвы». Кремль как общественный центр (из архива А.В. Щусева); г) 1922 год. Конкурсный проект Дворца труда. Архитекторы - братья Веснины (3 премия) 
вый опыт проектирования главного здания столицы мирового пролетариата, утверждавшегося во дворцах как господствующий класс: Дворце народов, заложенном в 1918 году, Дворце труда и, как апофеоз «дворцовой» темы, - в Дворце Советов.

Здание Дворца труда, включавшее множество помещений общественного и административного характера, не имело аналогий в мировой практике. Открытый международный конкурс на составление проекта был объявлен в ноябре 1922 года, что совпало с подготовкой к образованию Союза ССР (30 декабря 1922 г.). Во Дворце труда должны были разместиться: большой зал-аудитория на 8 тыс. мест, зал заседаний Моссовета на 2,5 тыс. мест, три лекционные аудитории на 300, 500 и 1000 мест, библиотека, читальные залы, музей социальных знаний, рабочие помещения Моссовета и Московского комитета партии, почта, телеграф и центральная радиостанция Москвы. Программой подчёркивалось, что здание должно «иметь богатый, соответствующий своей идее вид».

Дворец труда задумывался как часть комплекса правительственных зданий - напротив должно было возникнуть здание Государственного банка СССР. Впоследствии на этом месте по проекту А.Я. Лангмана в 1932-1935 годы было построено здание Совета труда и обороны (СТ0) - высшего органа Союза ССР, отвечавшего за руководство хозяйственным строительством и обороной страны (табл. 1).

Дворец труда не был построен - программа конкурса была обращена в будущее, что делало Дворец в большей мере футуристическим и экспериментальным объектом. Необходимо также отметить, что финансовые возможности советского государства не позволяли тратить средства на возведение столь значительных объектов.

Советская политико-правовая доктрина отвергала принцип разделения властей как буржуазный и неприемлемый для социалистического общества. Государственная власть была единой и провозглашалась как власть Советов, то есть представительных органов: «Высшим органом государственной власти СССР является Верховный Совет СССР. <...> 3аконодательная власть СССР осуществляется исключительно Верховным Советом ССС» [2, с. 15].

Наиболее отчётливо это было выражено в проекте Дворца Советов, где все высшие органы ветвей государственной власти - законодательная, исполнительная, судебная и главная власть в СССР - партийная, должны были находиться в одном здании.

Выбор места строительства Дворца Советов не был случаен. Новый представительный орган обеих ветвей советской государственной власти - законодательной и исполнительной, находившихся под руководством и контролем партии, занял место сакрального символа высшей, божественной власти - Храма Христа Спасителя. Не только место возведения было уникально по значению - Дворец Советов претендовал стать самым высоким зданием своего времени, превзойдя Эйфелеву башню и небоскрёб Эмпайр Стейт Билдинг (рис. 4).
Фактическое слияние ветвей советской власти определило градостроительную политику в отношении размещения высших органов государственной власти в столице СССР (см. рис. 1; рис. 5). Расчистка территории Кремля в 1920-1930-х

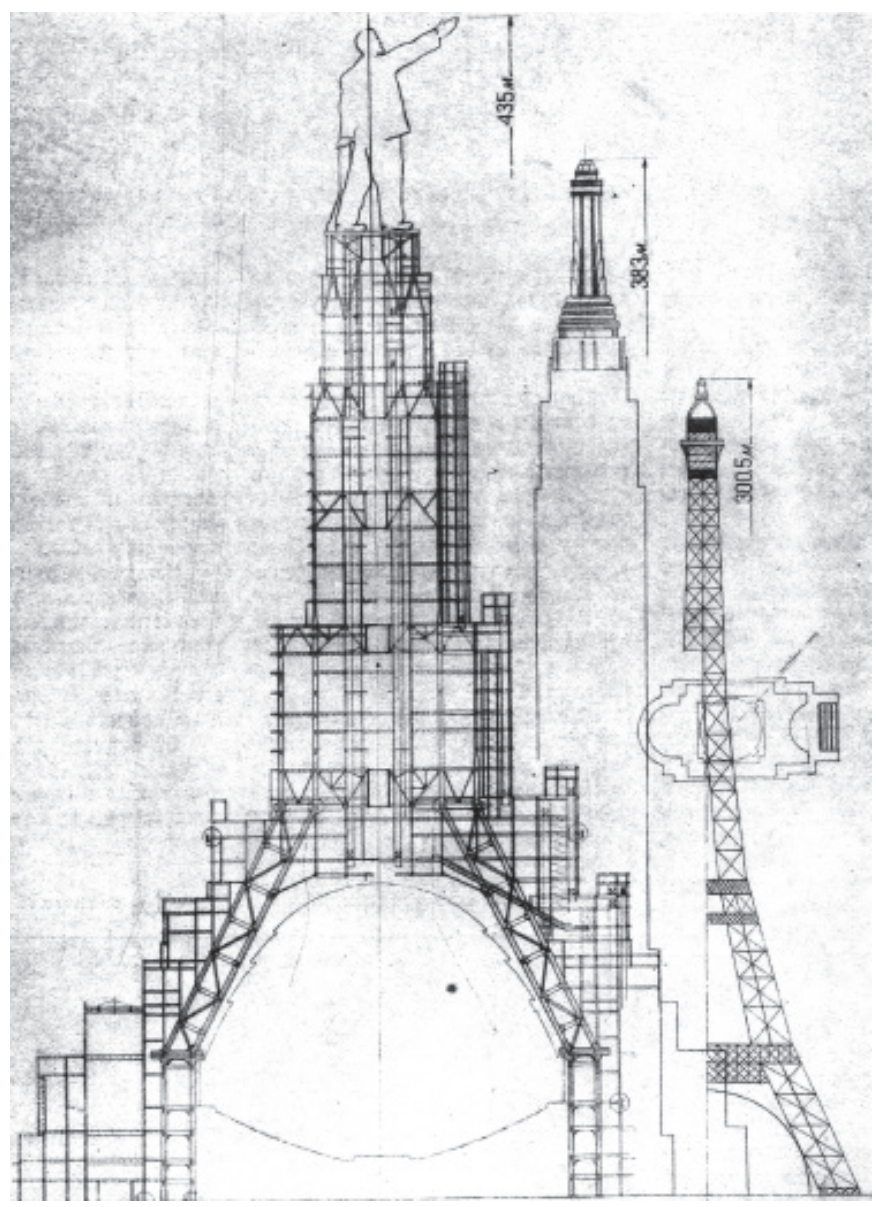

Рис. 4. 1936. Проект стального каркаса Дворца Советов (435 м) в сравнении с высочайшими зданиями в мире - Эйфелевой башней $(300,5$ м) и небоскрёбом Эмпайр Стейт Билдинг (383 м)

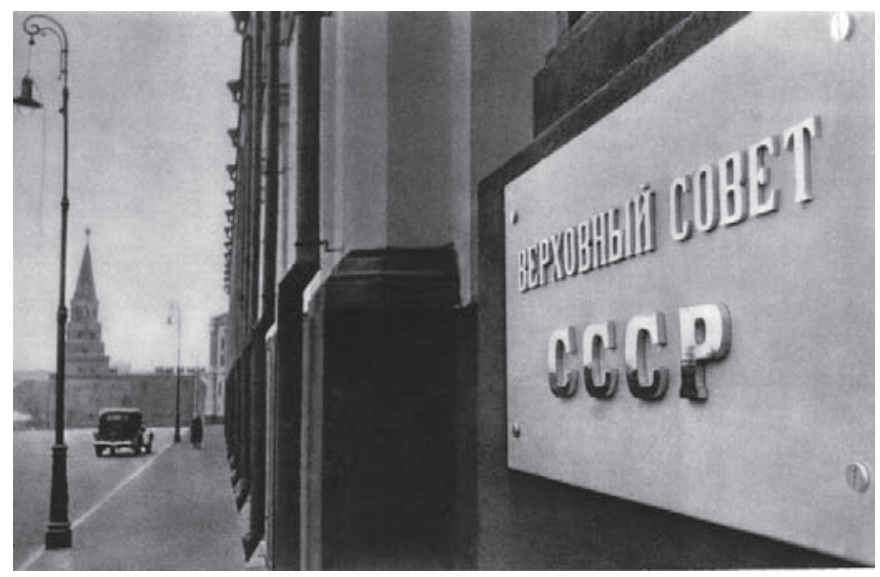

Рис. 5. 1947 год. Подъезд Большого Кремлёвского дворца, в котором в 1934-1962 годах размещался Верховный Совет СССР. Фото В.В. Ковригина 
Таблица 1. Здания высших органов власти РСФСР - СССР - Российской Федерации*

\begin{tabular}{|c|c|c|c|}
\hline 혇 & $\begin{array}{c}\text { Законодательная власть } \\
\text { Представительные и законодательные органы }\end{array}$ & Исполнительная власть & Судебная власть \\
\hline 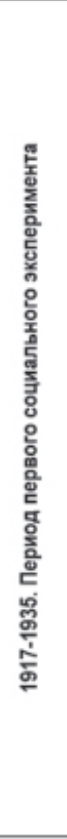 & 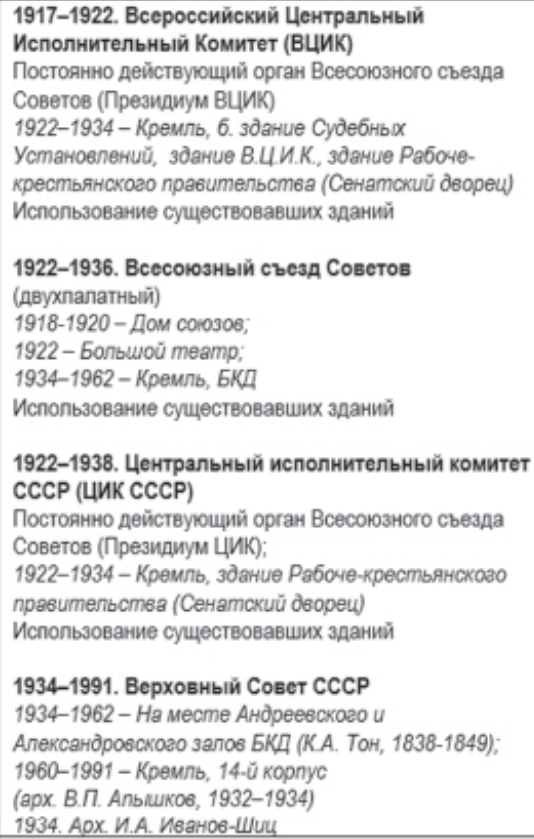 & $\begin{array}{l}\text { 1918-1922. Реввоенсовет } \\
\text { 2-й Дом Реввоенсовета (Средние } \\
\text { тораовые ряды) } \\
\text { Использование существовавших } \\
\text { зданий } \\
\text { 1923-1946. Совет народных } \\
\text { комиссаров СССР } \\
\text { 1923-1924- Кремль, здание В.Ци.К., } \\
\text { здание Рабоче-крестьянскозо } \\
\text { правительства (Сенатский дворец) } \\
\text { Кремль, Сенатский дворец } \\
\text { Использование существовавших } \\
\text { зданий } \\
\text { 1933-1994. Дом Комитетов } \\
\text { Совнаркома СССР } 6 \text { Охотном ряду } \\
\text { (кДом СТО:) } \\
\text { Охотный рнд, 1; } \\
\text { 1932-1935- проект и } \\
\text { строительство. } \\
\text { Арх. А.Я. Ланаман }\end{array}$ & 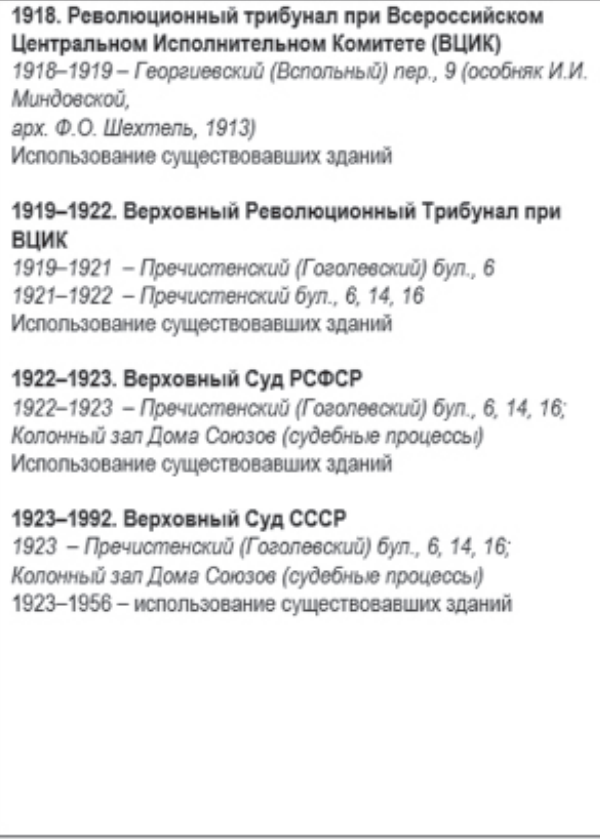 \\
\hline 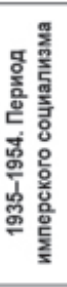 & & $\begin{array}{l}\text { 1946-1991. Совст министров СССР } \\
\text { Кремль, Сенатский дворец } \\
\text { Использование существовавших } \\
\text { зданий } \\
\text { 1949-1991. Совет экономической } \\
\text { взаимопомощи (СэВ) - орган } \\
\text { экономического и научно-технического } \\
\text { сотрудничества социалистических } \\
\text { стран }\end{array}$ & \\
\hline 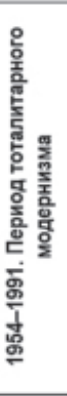 & $\begin{array}{l}\text { 1960-1991. Верховный Совет СССР } \\
\text { 14-ŭ корпус Кремля, арх. В.П. Альииков, 1932-1934; } \\
\text { Реконструкция 14-го корпуса Кремля } \\
\text { 1961. Кремлевский дворец сьездов (сьезды КПСС) } \\
\text { 1959-1961 - проект и строительство. Арх. М.В. } \\
\text { Посохин, А.А. Мндояни. Е.Н. Стамо, П.П. Штеллер и } \\
\text { др. } \\
\text { 1984-1992. Верховный Совет РСФСР, Комитет } \\
\text { народного контроля } \\
\text { Дом Советов РСФСР. Краснопресненская на6. } \\
\text { 1965-1981 - проект и строительстео. Арх. Д.Н. } \\
\text { Чечулин, П.П. Штеллер и др. }\end{array}$ & $\begin{array}{l}\text { 1949-1991. Совет экономической } \\
\text { взаимопомощи (СЭВ) } \\
\text { Н. Арбат, 36; } \\
\text { 1963-1970- проект и строительство } \\
\text { комплекса зданий секретариата СЭВ, } \\
\text { арх. М.В. Посохин, А.А. Мндояни, В.A. } \\
\text { Свирский и др. }\end{array}$ & $\begin{array}{l}\text { 1923-1992. Верховный Суд СССР } \\
\text { 1956-1992 - УЛ. Поварская, 13-15; } \\
\text { 1956- Проект и строительство. Арх. Б. П. Лейбо }\end{array}$ \\
\hline 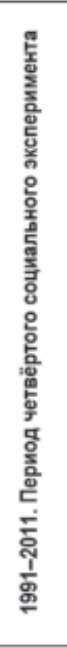 & 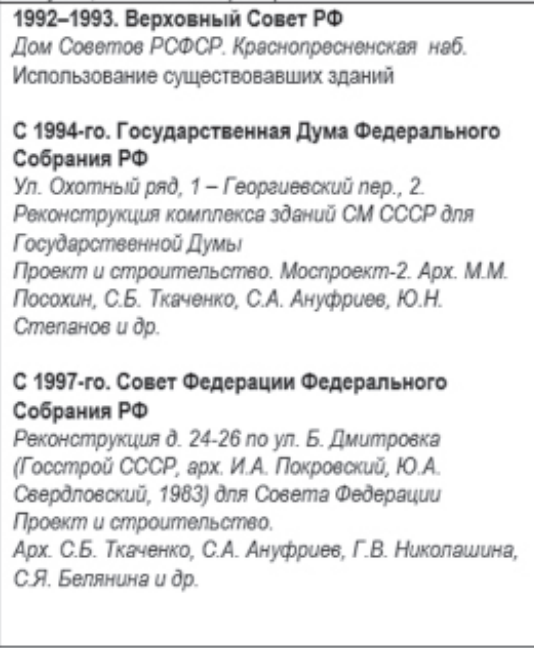 & $\begin{array}{l}\text { 1991-1993. Совет министров РСФСР } \\
\text { Дом Советов РСФСР. } \\
\text { Краснопресненская на6. } \\
\text { Использование существовавших } \\
\text { зданий } \\
\text { С 1993-го. Правительство РФ } \\
\text { Дом Правительства РФ. } \\
\text { Краснопресненская на6. } \\
\text { Восстановление после политического } \\
\text { конфликта в } 1993\end{array}$ & 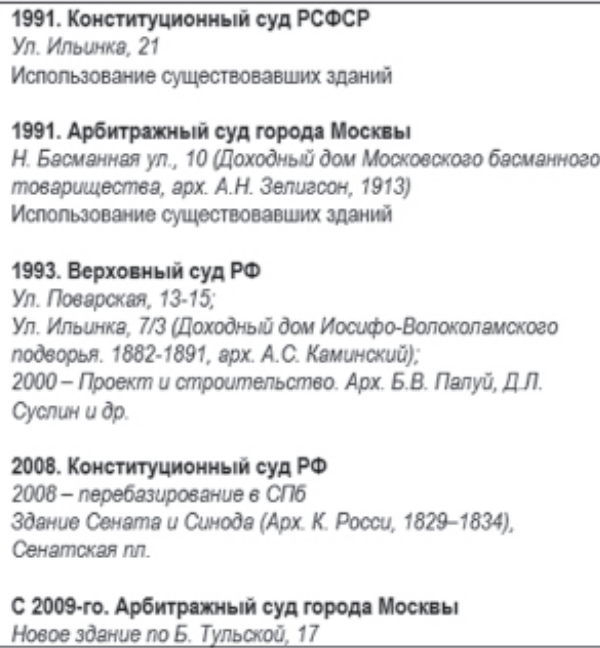 \\
\hline
\end{tabular}

* Составлено С.Б.Ткаченко 
годах от монастырей, палат и дворцов и строительство на их месте новых зданий позволили сконцентрировать там резиденции исполнительной и законодательной власти. Конкурсные проекты Дворца Советов на Ленинских горах $(1957,1959)$ не были реализованы (табл. 2). Строительство Кремлёвского дворца съездов закрепило центростремительную стратегию размещения высших органов власти (табл. 1; рис. 6).

Правоохранительная и правоприменительная система, подведомственная Советам, Наркомюсту и НКВД, была сформирована в СССР до конца 1920-х годов [3]. Образец советского правосудия периода имперского социализма (1935-1954) - репрессивная практика заочного принятия решений «тройками» НКВД (1937-1938), не требовала специализированных зданий и помещений, приспособленных под исполнение судебных процедур и ведение судопроизводства. Выездные судебные заседания проводились в театральных залах, дворцах и клубах культуры, на предприятиях. Образ «зала массовых действий» сливался с образом «карающего меча» советской власти.

Следствием позиции судебной власти в советской властной иерархии стало положение, при котором и Ревтрибунал при ВЦИК, и Верховный Суд РСФСР и СССР с 1919 по 1956 год размещались в дореволюционных особняках на Пречистенском бульваре. Лишь в 1956 году Верховный Суд СССР получил новое здание, выстроенное на Поварской улице во вл. 13-15 по проекту архитектора Б.П. Лейбо (см. табл. 1).

Следующая смена социально-политической формации произошла после распада Советского Союза. 12 июня 1990 года Съездом народных депутатов была принята Декларация о государственном суверенитете РСФСР, 8 декабря 1991 года Беловежскими соглашениями было закреплено прекращение существования СССР. 25 декабря 1991 года Верховным Советом РСФСР страна была переименована в Российскую Федерацию. В соответствии со статьёй 70 Конституции, принятой 12 декабря 1993 года, столицей Российской Федерации стал город Москва.

Поворотным этапом перехода от социалистической к новой политико-социальной формации стала отмена роли КПСС - руководящей и направляющей силы советского общества, ядра его политической системы, государственных и общественных организаций. Избранный в 1990 году российский парламент - Верховный Совет Российской Федерации, был независимым и действительно работал как законодательная власть.

В 1993 году, после того, как возникло противостояние законодательной и исполнительной ветвей власти, Верховный Совет был упразднён. Произошло конституциональное изменение структуры ветвей власти, что привело к появлению новых высших органов государства: Совета Федерации, Государственной Думы, Правительства и судебных органов Российской Федерации. Этот процесс 1993 года, сопровождался перемещением высших органов власти из одних зданий в другие. Так, после обстрела Дома Советов РФ на
Краснопресненской набережной - Белого дома, из него были выведены органы законодательной власти.

Государственная Дума Федерального Собрания - орган законодательной власти РФ - была перемещена из Белого дома на Краснопресненской набережной в дом № 1 по 0хотному ряду. Это произошло в начале 1994 года. Реконструкция, длившаяся 5,5 месяцев одновременно с проектными работами, была поручена Моспроекту-2. Уже в сентябре 1994 года очередная сессия Госдумы проходила в комплексе зданий в 0хотном ряду, приспособленных под работу законодательной власти.

В советское время в генеральных планах реконструкции и развития Москвы планирование столичных функций города было учтено в ряде разделов. Особое внимание к осуществлению Москвой столичных функций, требовавшему отражения в документах территориального планирования, стало возникать с конца 1990-х годов.

В «0сновных направлениях градостроительного развития Москвы и Московской области на период до 2010 г.» были указаны секторы народнохозяйственного комплекса, в которых происходили «перспективные структурные сдвиги», обеспечивавшие «...эффективное взаимодействие с международным и внутренним рынком, мобилизацию столичных интеллектуальных, историко-культурных, инновационных и научно-технических ресурсов». К объектам таких секторов был отнесён «комплекс федеральных органов власти и управления, иностранных представительств и международных организаций» [4, с. 26].

Раздел планирования градостроительных обязательств по осуществлению столичных функций появился в Генеральном плане развития Москвы до 2020 года.

В части 4 Генерального плана развития города Москвы до 2025 года: «Обеспечение интересов Российской Федерации в развитии столицы Российской Федерации - города федерального значения Москвы», подробно указаны задачи территориального планирования в части осуществления городом

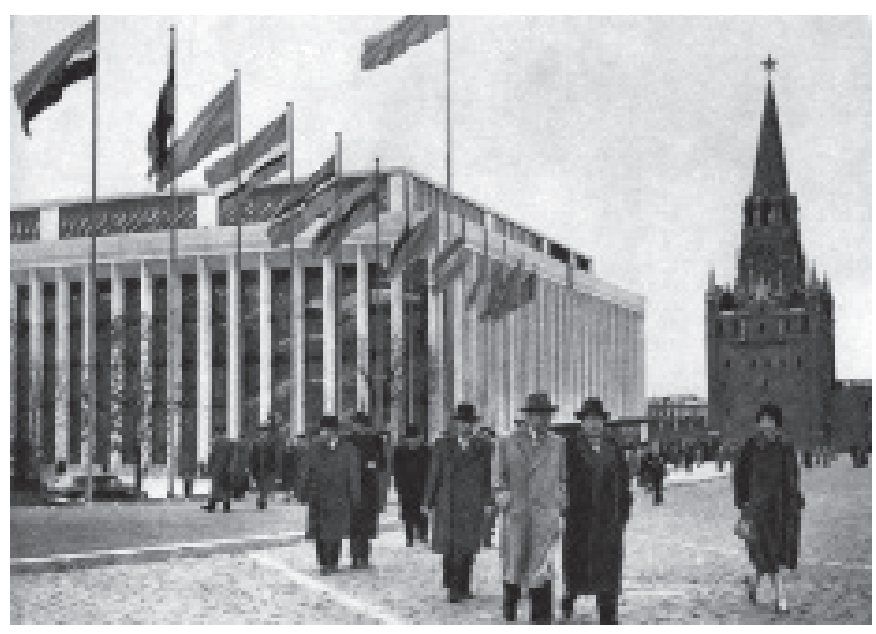

Рис. 6. 1962 год. Кремлёвский Дворец съездов, в котором в 1961-1990 годы проводились съезды КПСС. Почтовая карточка 
функций столицы Российской Федерации. В числе прочих предусматривалось создание градостроительных условий для проведения общегосударственных мероприятий, в том числе проведение массовых публичных акций, а также организация общественных пространств [5]. Удельная площадь общественных церемониальных пространств Москвы - 43 кв.м/ 1 тыс.жит., уступает показателям других столиц. В Лондоне это 185 кв.м/1 тыс.жит., Париже 350 кв.м/1 тыс.жит., Нур-Султане 1160 кв.м/1 тыс.жит., Вашингтоне 3660 кв.м/1 тыс.жит. [6].
Торжественная церемония вступления главы государства в должность отражает не только форму политико-социальной формации, но и приспособленность общественных пространств, формируемых ансамблями зданий высших органов ветвей государственной власти - представительской законодательной, исполнительной и судебной, к выполнению столицей государства своих столичных функций.

Первый российский президент Б.Н. Ельцин вступил в должность 10 июля 1991 года. Его инаугурация проводилась

Таблица 2. Основные концепции размещения зданий высших органов власти РСФСР - СССР - Российской Федерации*

\begin{tabular}{|c|c|c|c|}
\hline Период & $\begin{array}{c}\text { Законодательная власть } \\
\text { Представительные и законодательные органы }\end{array}$ & Исполнительная власть & Судебная власть \\
\hline \multirow{4}{*}{ 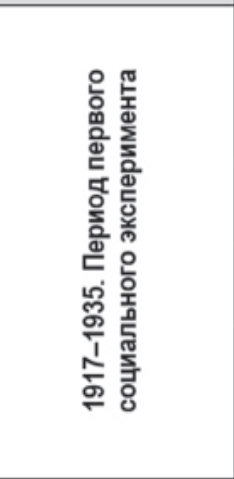 } & \multicolumn{2}{|c|}{$\begin{array}{l}\text { 1918. Эскизный проект перепланировки Москвы } \\
\text { 1923. Проектный план «Новой Москвы» } \\
\text { Всесоюзный административно-политический центр СССР на Ходынском поле. Арх. И.В. Жолтовский, А.В. } \\
\text { Щусев и др. }\end{array}$} & \\
\hline & \multicolumn{2}{|l|}{$\begin{array}{l}\text { 1922-1923. Дворец Труда (открытый международный конкурс) } \\
\text { Охотный ряд }\end{array}$} & \\
\hline & \multicolumn{2}{|l|}{$\begin{array}{l}\text { 1931. Дом съездов (конкурс) } \\
\text { Охотный ряд. Выработка программы конкурса на Дворец Советов }\end{array}$} & \\
\hline & \multicolumn{2}{|c|}{$\begin{array}{l}\text { 1931-1933. Дворец Советов Союза СССР (международный конкурс) } \\
\text { Проведение съездов партии } \\
\text { Варианты размещения: на месте Храма Христа Спасителя, в Охотном ряду, на Воробьевых горах, } \\
\text { Хамовническом валу }\end{array}$} & \\
\hline $\begin{array}{l}\text { 1935-1954. Период } \\
\text { имперского } \\
\text { социализма }\end{array}$ & & $\begin{array}{l}\text { 1940. Второй Дом Совнаркомов } \\
\text { СССР (конкурс) Зарядье. } \\
\text { Арх. В.А. и А.А. Веснины, } \\
\text { Г.М. Орлов, В.А. Лавров, } \\
\text { А.Г. Чиняков } \\
\text { Строительство прекращено в } \\
1941\end{array}$ & \\
\hline $\begin{array}{l}\text { 1954-1991. Период } \\
\text { тоталитарного } \\
\text { модернизма }\end{array}$ & \multicolumn{2}{|l|}{$\begin{array}{l}\text { 1957, 1959. Дворец Советов в Москве (всесоюзный открытый конкурс) } \\
\text { Проведение съездов партии } \\
\text { Ленинские горы }\end{array}$} & \\
\hline \multirow{6}{*}{ 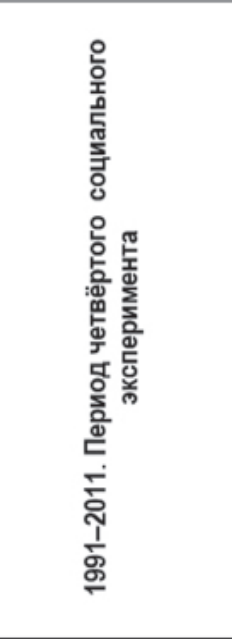 } & $\begin{array}{l}\text { 1996. Парламентский центр РФ } \\
\text { Развитие комплекса Воспитательного дома } \\
\text { на Москворецкой наб. Арх. М.М. Посохин и др. }\end{array}$ & & \\
\hline & $\begin{array}{l}\text { 1998. Конгресс-центр Федерального Собрания РФ } \\
\text { Цветной бул., 2. Арх. С.Б. Ткаченко и др. }\end{array}$ & & \\
\hline & $\begin{array}{l}\text { 2001. Совет Федерации Федерального Собрания РФ } \\
\text { Развитие комплекса зданий по ул. Б. Дмитровка, 24-26. Арх. С.Б. } \\
\text { Ткаченко и др. }\end{array}$ & & \\
\hline & $\begin{array}{l}\text { 2005. Парламентский центр РФ } \\
\text { Площадь Федерации-Манежная пл.-Охотный ряд (после сноса } \\
\text { гостиницы «Москва»). Арх. Ю.П. Бочаров }\end{array}$ & & \\
\hline & $\begin{array}{l}\text { 2006-2007. Парламентский центр РФ } \\
\text { Дружинниковская ул., } 18 . \\
\text { Арх. С.Б. Ткаченко, М.Д. Хазанов и др. }\end{array}$ & & \\
\hline & $\begin{array}{l}\text { 2008-2012. Парламентский центр РФ } \\
\text { Зарядье. Моспроект-2 }\end{array}$ & & \\
\hline \multirow{2}{*}{$\begin{array}{l}\text { С } 2011 . \\
\text { Этап } \\
\text { авторитарного } \\
\text { реновизма }\end{array}$} & $\begin{array}{l}\text { 2012. Федеральный центр (международный конкурс на проект } \\
\text { развития Московской агломерации) } \\
\text { Пос. Коммунарка (на присоединенных территориях Московской обл.) }\end{array}$ & & \multirow{2}{*}{$\begin{array}{l}\text { 2014-2016. } \\
\text { Судебный квартал } \\
\text { в Санкт- } \\
\text { Петербурге } \\
\text { Васильевский } \\
\text { остров }\end{array}$} \\
\hline & $\begin{array}{l}\text { 2015. Парламентский центр РФ (конкурс) } \\
\text { Нижние Мневники }\end{array}$ & & \\
\hline
\end{tabular}

* Составлено С.Б.Ткаченко 
в Кремлёвском дворце съездов. С 2000 года инаугурация президента Российской Федерации проводится в Андреевском зале Большого Кремлёвского дворца - парадной резиденции президента Российской Федерации. Патриархом Московским и Всея Руси проводится праздничный молебен, устанавливающий преемственность инаугурации президента с коронацией российских императоров. Завершается инаугурация парадом президентского полка на Соборной площади, который принимает вступивший в должность президент. Сценарий инаугурации и парад составлены для ограниченного количества приглашённых - представителей элит российского общества. На инаугурацию 2012 года были приглашены более двух тысяч человек, на инаугурацию 2018-го - около пяти тысяч гостей (рис. 7) [7].

Можно прийти к выводу, что ни здания высших органов законодательной власти, ни общественные пространства столицы - города Москвы, не приспособлены к проведению массовых мероприятий, связанных со вступлением в должность президента Российской Федерации. Таким образом, имеет место административный и культурно-исторический градостроительный конфликт, который «...возникает тогда, когда территория, находящаяся в процессе развития городской среды под влиянием одних участников, приобретает такую форму, которая прямо противоречит представлениям о развитии других пользователей» [8].

После 1991 года в Москве стали действовать новые факторы, влиявшие на территориальное планирование столицы, связанные с общественными пространствами - местами проведения массовых общественных действий, митингов и протестных демонстраций. Наметилась тенденция к ликвидации церемониальных открытых пространств города, необходимых для выражения общественного мнения населением столицы и страны. В период четвёртого социального эксперимента (1991-2011), а в особенности на этапе авторитарного реновизма московского градостроительства (с 2011) [9], стала происходить трансформация главных площадей столицы. Наиболее показательной стала эволюция двух центральных московских площадей - Манежной и Триумфальной.

С 1987 года Манежная площадь стала территорией проведения у стен Кремля несанкционированных митингов и демонстраций всевозможной направленности - от патриотов и активистов общества «Память» до сторонников Б.Н. Ельцина, от противников КПСС до футбольных фанатов. В 1993 году на площади начались строительные работы, в результате которых возник полуподземный торговый центр «0хотный ряд». Площадь утратила свою историческую планировку, сложившуюся в 1930-х годах после сноса средовой застройки, но архитектурный ансамбль в целом сохранился. При этом архитектурные цели проекта были возвышенными: «...взаимодействие с наземной частью города, который таким образом будет развиваться в трёхмерном пространстве вместо двухмерного» [10].

Ознакомившись с проектом, президент Б.Н. Ельцин его одобрил: «0чень хорошо, Анпилову негде будет устраивать демонстрации» [11].
Снос гостиницы «Москва» продемонстрировал возможность организации площади Федерации - главного церемониального пространства России, обрамлённого зданиями высших органов власти, на которой при стечении огромных масс народа может проводиться инаугурация президента Российской Федерации (рис. 8). Предложения архитектора (Ю.П. Бочаров) не совпали с намерениями ни федеральных, ни столичных властей.

Площадь Маяковского (с 1992 года Триумфальная) после установки в 1958 году памятника В.В. Маяковскому стала пространством для поэтических чтений шестидесятников, а впоследствии и неофициальных акций. Это заложило традицию «оппозиционности» площади. С 2009 года сторонники так называемой «Стратегии-31», выступавшие в защиту 31 статьи Конституции о свободе собраний, стали проводить каждое 31 число месяца на Триумфальной площади несанкционированные митинги. В 2010 году пешеходную часть площади закрыли для производства археологических изысканий, предшествовавших строительству многоуровневой автостоянки. В дальнейшем, после 2011 года, со сменой стратегии транспортного обслуживания центра и введением тактики «репрессий для автомобилей», от стоянки отказались. Но задача «защиты» площади от активной части населения осталась. Решение было найдено с помощью архитекторов. После проведения в 2014 году конкурса на благоустройство Триумфальной площади она полностью изменила

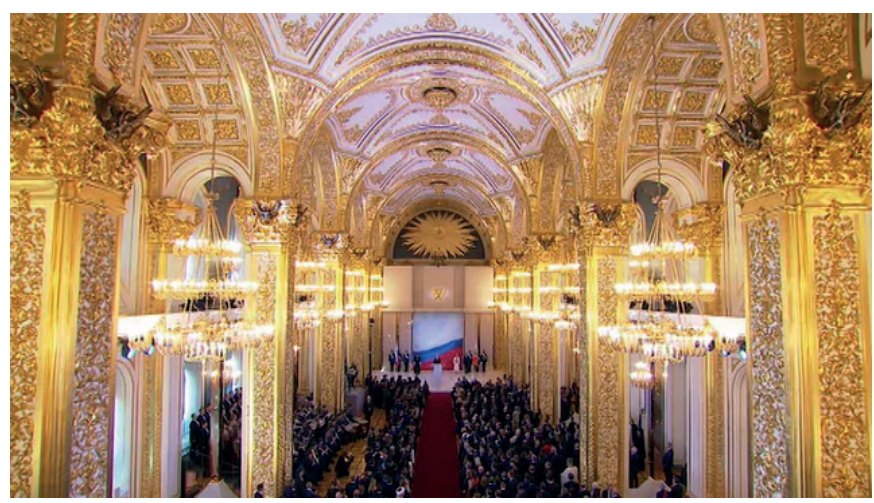

Рис. 7. 2012 год. Андреевский зал Большого Кремлёвского дворца. Вступление в должность президента Российской Федерации. На церемонию инаугурации приглашено более двух тысяч гостей

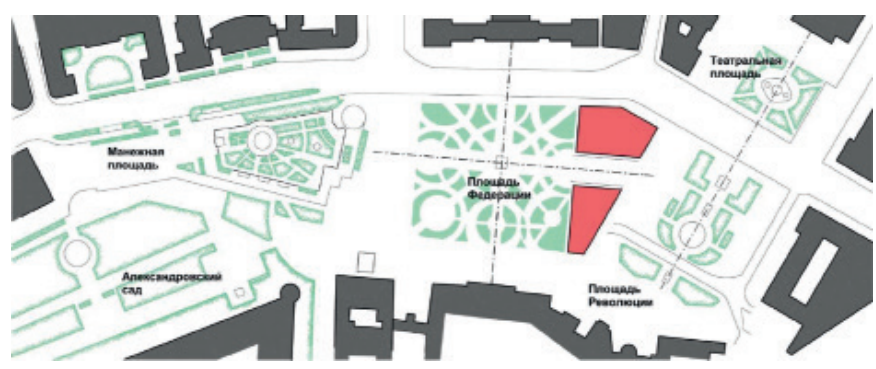

Рис. 8. 2005 год. Проект площади Федерации - главного церемониального пространства России, на которой может проводиться публичная инаугурация президента Российской Федерации. Архитектор Ю.П. Бочаров 
свои градостроительные характеристики и социальную направленность. Был реанимирован проект реконструкции Садово-Триумфальной площади, составленный А.В. Щусевым в 1933 году, по которому в центральной части образовывалась приподнятая платформа [12]. Качели возродили традицию праздничных гуляний середины XIX века, когда, как описывал М.Н. Загоскин, за городской чертой строились качели, карусели и балаганы, народ водил хороводы и посещал питейные заведения. Озеленение, мощение, киоски и разновысокие скамейки превратили торжественный ансамбль столичной площади в удобное, полупешеходное расширение общественного пространства Тверской улицы. Исчез хрестоматийный вид на Садовое кольцо, градостроительный ансамбль с монументом превратился в дробную смесь разнохарактерных проходов, двориков и скверов.

Многие общественные пространства Москвы после 2011 года подверглись переосмыслению. Бульвары, площади и пешеходные зоны заполнились торговыми павильонами и киосками, монументальными стендами фотовыставок и ещё более монументальными декорациями - многоуровневыми арками, дизайнерскими композициями, малыми формами. Борьба градозащитников периода 1990-2000-х за свободу исторического центра от диссонировавшего вмешательства временных зданий и сооружений, нарушавших визуальную чистоту восприятия, потерпела сокрушительное поражение. На Тверской площади, перед зданием мэрии, памятник основателю Москвы Юрию Долгорукому заблаговременно обстроили павильонами, перекрестия карнизов которых отсылали к воспоминаниям о противотанковых ежах времён обороны Москвы в 1941 году.

Преображение площади Красных ворот в 2017 году также было связано с ликвидацией открытого пространства. Площадь покрыли закамуфлированные газоном и деревьями метровые земляные надолбы и эскарпы, оставив отдельные лучи восприятия искусно скрытого конструктивистского портала вестибюля станции метрополитена «Красные ворота» (Н.А. Ладовский, 1935). Вместо знаменитой московской площади появился труднопроходимый сквер, выстроенный по проекту КБ «Стрелка» и архитектора М. Девинь (Франция).

Поиск достойного места в столице для комплексов зданий высших органов власти начался сразу после переезда советского правительства из Петрограда в Москву. Первые концепции в соответствии со стратегией структурирования властных полномочий предусматривали совместную работу законодательной и исполнительной власти, и только в период четвёртого социального эксперимента (1991-2011) главной темой стало размещение Федерального Парламентского центра (табл. 2). Большая часть этих концепций относится к категории неосуществлённых градостроительных проектов (табл. 2; см. рис. 2).

В начале 1990-х годов исполнительная власть страны была вынуждена искать поддержки у национально-патриотических движений и Российской православной церкви. Результатом стало восстановление роли РПЦ в общественной жизни государства. Стратегия «неполной реституции», а также решения о выделении участков для строительства храмов и, прежде всего, о воссоздании храма Христа Спасителя, нашли отражение в столичном градостроительстве. В 1994 году работы по воссозданию были поручены мэру Москвы Ю.М. Лужкову, и в 2000 году в храме прошла первая служба. Место строительства Дворца Советов, временно сохранявшееся под бассейном «Москва», было вновь возвращено церкви.

Идея создания Парламентского центра Российской Федерации стала набирать силу после восстановления Дома Правительства РФ на Краснопресненской набережной и реконструкции «Дома СТ0» в Охотном ряду для размещения Государственной Думы Федерального Собрания РФ (архитекторы М.М. Посохин, С.Б. Ткаченко и др., 1994).

Одной из первых концепций Парламентского центра стали проектные предложения по приспособлению под эти цели Воспитательного дома на Москворецкой набережной (архитекторы М.М. Посохин, Т.В. Малявкина, 3.В. Харитонова, 1996). Занимавшую Воспитательный дом Военную академию РВСН имени Петра Великого планировалось передислоцировать на юго-запад, в сложившийся комплекс высших специальных учебных заведений (рис. 9).

В связи с ограниченной площадью Воспитательного дома, защищённого статусом памятника культурного наследия, концепция была дополнена предложениями о развитии комплекса Парламентского центра за счёт включения в него зданий по нечётной стороне Китайгородского проезда (Министерство энергетики РФ, Министерство культуры РФ и др.) до Воспитательного проезда (архитекторы С.Б. Ткаченко, С.А. Ануфриев и др., 1999). В этом случае обе палаты законодательной власти государства - Совет Федерации и Государственная Дума Федерального Собрания Российской Федерации, могли получить необходимые и достаточные площади для своей работы.

В 1998 году была разработана инициативная концепция размещения законодательной власти в Конгресс-центре Федерального Собрания РФ при реконструкции или сносе Дома политпросвещения на Цветном бульваре, 2 (рис. 10). Концепция не была реализована, так как заказчик предпочёл выстроить на этом земельном участке жилой комплекс «Легенда Цветного».

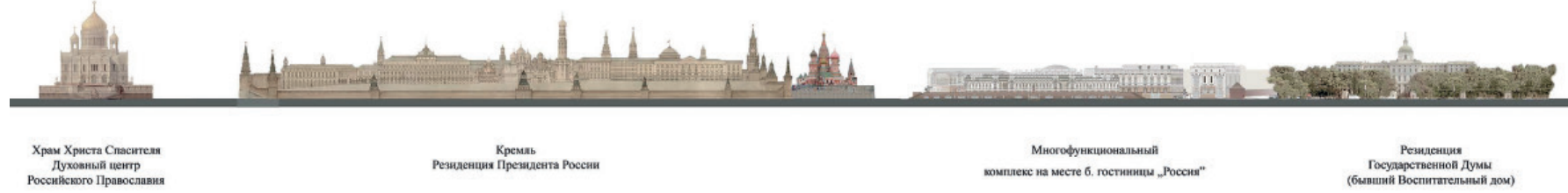

Pис. 9. 1996 год. Предложение по размещению Парламентского центра Российской Федерации на Москворецкой набережной. Моспроект-2. Архитекторы М.М. Посохин и др. 
По поручению Управления делами Президента Российской Федерации в 2006-2007 годах была выполнена концепция и проект планировки для Парламентского центра Российской Федерации на Дружинниковской улице, 18, на месте стадиона «Красная Пресня» (рис. 11). Продвинуться дальше документации территориального планирования не позволило отношение жителей кутрате располагавшегося на этом месте стадиона.

В программу международного конкурса на проект развития Московской агломерации (2012) была включена инициатива Президента Российской Федерации Д.А. Медведева о строительстве Федерального центра на территориях Московской области, присоединённых к Москве, - в посёлках Коммунарка и Газопровод, в 4-х километрах от МКАД (рис. 12).

После отказа законодательной власти переезжать на присоединённые территории, в 2015 году был проведён конкурс на проект Парламентского центра на территории района Нижние Мнёвники. Ни один из трёх финальных проектов одобрен не был.

Планы перемещения касались не только законодательных органов. Стратегия децентрализации ветвей власти привела к идее перебазирования из Москвы Верховного суда. В 2014 году вышел Закон о Верховном суде Российской Федерации, в котором местом его постоянного пребывания был назван Санкт-Петербург. В 2016 году была одобрена концепция строительства Судебного квартала - зданий для высшего судебного органа государства - рядом с Петропавловской крепостью. Строительные работы планировалось завершить к 2021 году [13], однако в 2019 году Президент Российской Федерации во время посещения Санкт-Петербурга принял решение о создании вместо Судебного квартала «Арт-парка» по образу и подобию московского Зарядья [14]. Ситуация похожа: в Зарядье после сноса гостиницы «Россия» одним из вариантов застройки планировалось создать новый Правительственный центр (рис. 13), но в 2017 году по решению президента там был разбит парк.

Начало 2019 года было отмечено решением правительства Российской Федерации о переводе центральных аппаратов Минкомсвязи, Минпромторга, Минэкономразвития в одно из высотных зданий ММДЦ «Москва-Сити» «...в рамках совершенствования организации деятельности федеральных органов исполнительной власти, улучшения межведомственного взаимодействия, повышения качества выполнения государственных функций, оптимизации затрат на содержание и внедрение нового подхода к обеспечению деятельности федеральных органов» [15].

42-этажную башню IQ-квартала, в которую планировался переезд пяти тысяч чиновников, посетил Председатель Правительства Д.А. Медведев - инициатор создания в 2011 году Федерального центра в Коммунарке, на присоединённых территориях, и фактически одобрил новую версию формирования правительственного центра на базе высотного комплекса ММДЦ «Москва-Сити».

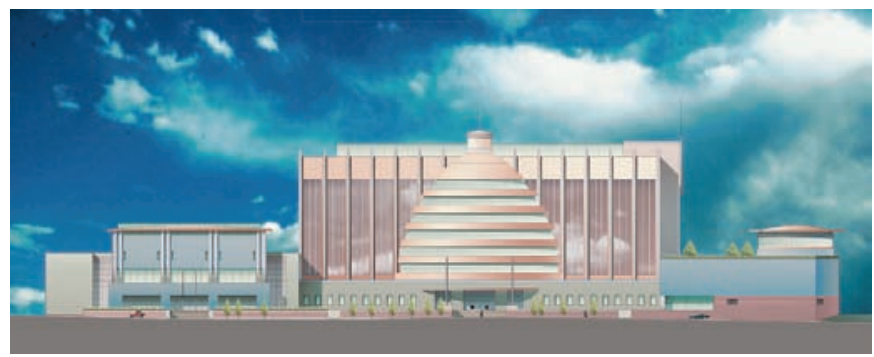

Рис. 10. 1998 год. Предложение по строительству Конгресс-центра Федерального Собрания Российской Федерации на Цветном бульваре, 2. Архитекторы С.Б. Ткаченко, С.А. Ануфриев, Г.В. Николашина и др.

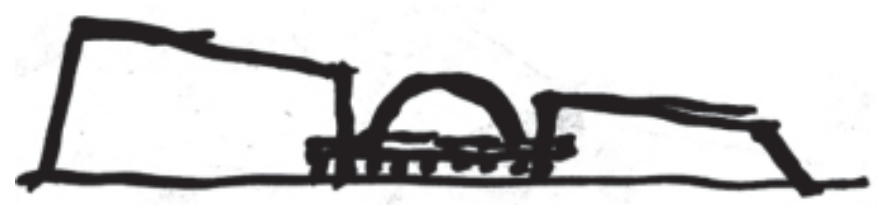

a)
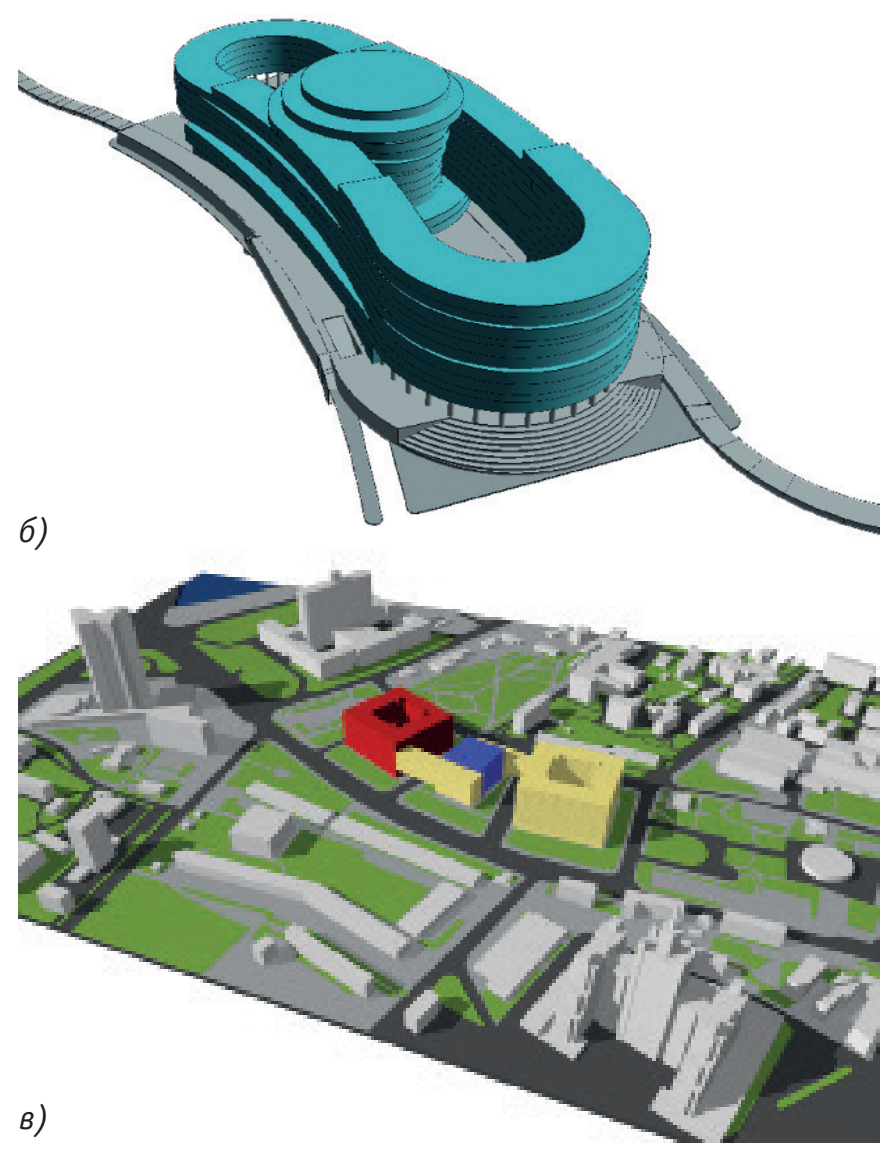

Рис. 11. 2006-2007 годы. Проект Парламентского центра Федерального Собрания Российской Федерации на Дружинниковской улице, 18. Архитекторы С.Б. Ткаченко, М.Д. Хазанов, А.Ф. Орлов, О.Л. Дубровский, И.И. Вознесенский, А.В. Кононенко и др.: а) 2006 год. Эскиз; б) вариант объёмно-пространственного решения; в) 2007 год. Одобренный заказчиком вариант, послуживший основой для разработки проекта планировки 


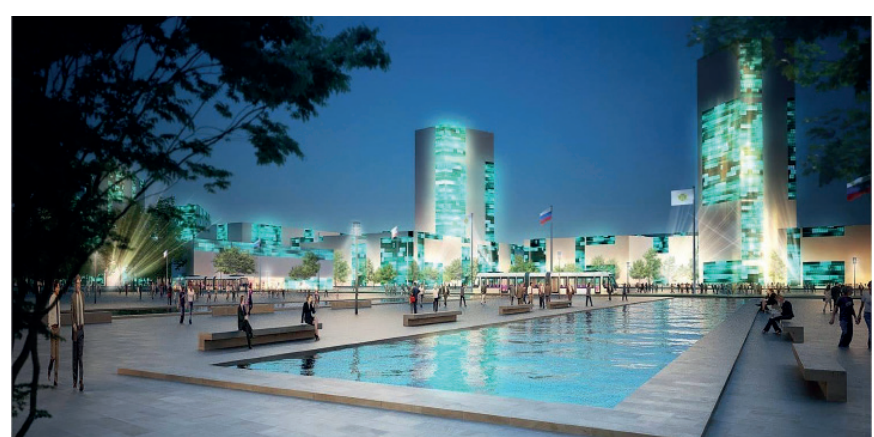

a)

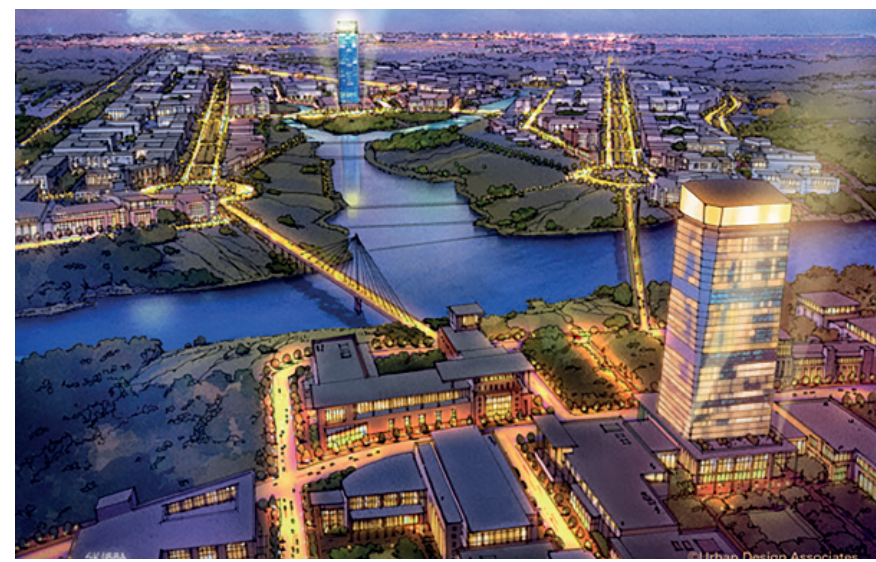

б)

Рис. 12. 2012 год. Международный конкурс на проект развития Московской агломерации: Федеральный центр: а) проект консорциума Грюмбах-Вильмотт-Ткаченко (Франция-Россия); б) проект UDA (Великобритания-США)

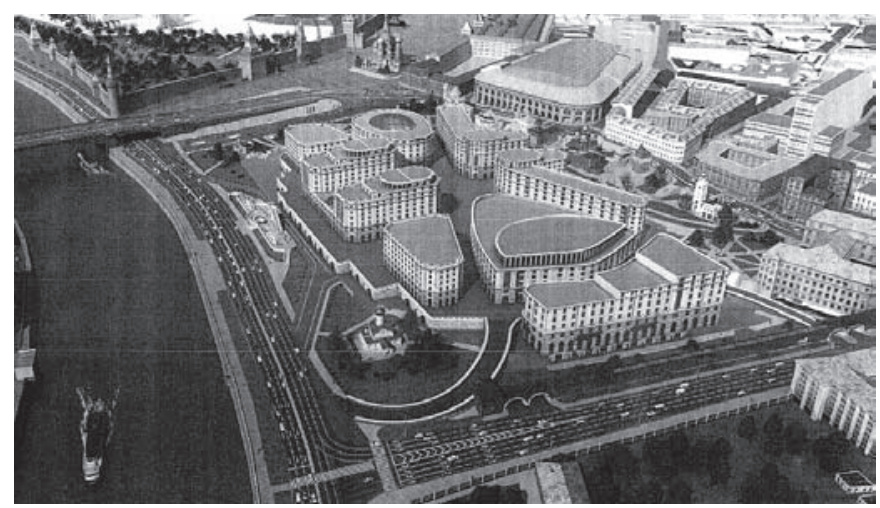

a)

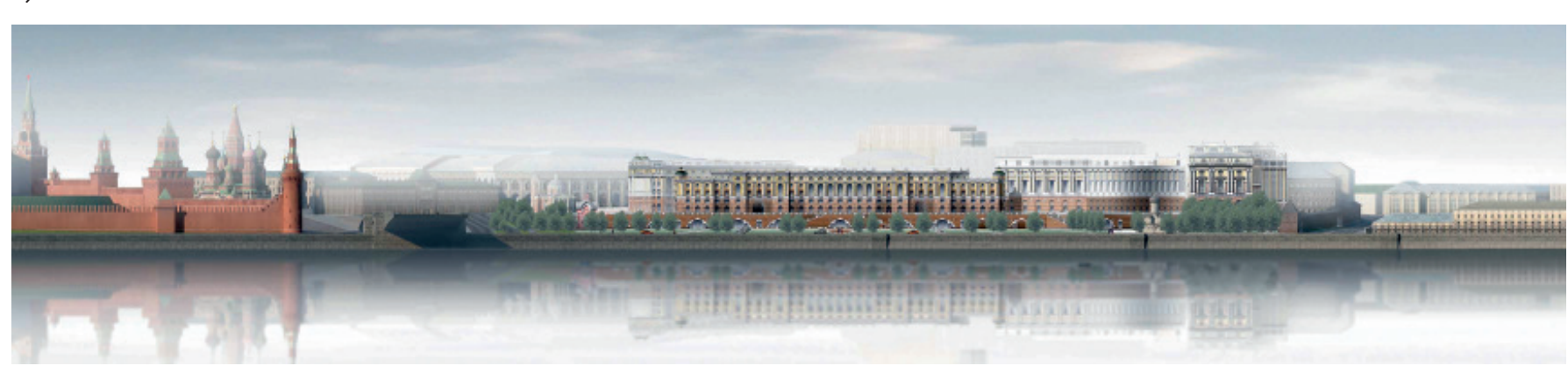

б)

Рис. 13. Проект развития территории района Зарядье (улица Варварка, вл. 6, кв. 20-25) с возможностью размещения Парламентского центра РФ. Моспроект-2: а) проект 2010 года; б) панорама 2008 года;
Необходимо отметить, что изменения в политической структуре России не вызвали возникновения стратегии размещения высших органов федеральной власти в столице, что явно противоречит парадигме столичности. Поручения правительства и инициативные концепции размещения Федерального Парламентского центра за 25 лет не получили развития, направленного на их реализацию (табл. 2; см. рис. 2). Создание подмосковных государственных резиденций в Ново-Огарёво (по аналогии с «ближней дачей» И.В. Сталина в Кунцево) и «Горки-9» не привело к децентрализации комплексов зданий высших органов власти.

Указанные противоречия усиливает отсутствие градостроительных решений по реализации общенациональной идеи формирования России как устойчивого государства. Основные федеральные структуры ветвей государственной власти, образованные в начале 1990 -х годов, как правило, до сих пор расположены в приспособленных зданиях бывших ведомств Союза ССР. Градостроительная политика «приспособления» априори исключила перспективу возникновения масштабных центров власти в столице - ансамблей зданий высших органов власти и сопутствующих им общественных пространств для реализации конституционных прав граждан на свободное волеизъявление.

Столицы ведущих стран мира имеют полицентрический принцип формирования градостроительной структуры, что соответствует демократической структуре общества и власти. Аналогичная задача может быть очередной раз поставлена и перед столицей Российской Федерации: «Целенаправленное формирование в столице России Парламентского, Правительственного и Судебного комплексов, выявление в структуре города функций Москвы как мирового культурного центра, центра страны, Московской области и Московской агломерации может создать объективные предпосылки полицентрического развития» [16].

Пространственное разделение комплексов зданий законодательной, исполнительной и судебной власти, символизирующее независимость государственных функций, приведёт к созданию нового масштаба города Москвы, соответствующего парадигме столичности. 


\section{Лuтература}

1. Бонч-Бруевич, В.Д. Переезд Советского правительства из Петрограда в Москву : (По личным воспоминаниям) / В.Д. Бонч-Бруевич. - М. : Жизнь и знание, 1926. - 19 с. - (Библиотека документов, записок и воспоминаний : Кн. 11).

2. Конституция (Основной закон) Союза Советских Социалистических Республик. Утверждена Чрезвычайным VIII съездом Советов Союза ССР 5 декабря 1936 года. - М. : ОГИЗ, 1937. - 36 с.

3. Борозинец, Ю.О. История судебной системы России эпохи СССР 1917-1930-х гг. / Ю.0. Борозинец // Инновационная наука. - 2015. - № 7. - С. 64-67.

4. Основные направления градостроительного развития Москвы и Московской области на период до 2010 г. - М. : Москомархитектура, НИиПИ Генплана Москвы, 1993. - 95 с.

5. 0 Генеральном плане города Москвы: закон города Москвы № 17 от 05.05.2010 // Вестник Мэра и Правительства Москвы, 03.06.2010. - Спецвыпуск № 1. - Тт. 1, 2, 3. - Ст. 2.3, 3.3.

6. Бочаров, Ю.П. Общественные пространства Москвы в условиях становления гражданского общества / Ю.П. Бочаров, Э.А. Сиренко // Academia. Архитектура и строительство.. - 2012. - № 2. - С. 101-105.

7. Путин вступил в должность президента. Сравниваем четыре инаугурации [Электронный ресурс] // BBC. News. Pycская служба. 7.05.2018 [сайт]. - Режим доступа: https://www. bbc.com/russian/news-44027663 (дата обращения 25.06.2019).

8. Конченков, С.М. Процессуальные характеристики градостроительного конфликта // Архитектон: известия вузов. 2018. - № 3 (63) - С. 1-12. ISSN 1990-4126.

9. Ткаченко, С.Б. Один век московского градостроительства. Кн. 1. Москва социалистическая / С.Б. Ткаченко. - М. : Улей, 2018. - 312 с.

10. Назарова, Л.С. Мечты о Манежной площади: подземное пространство как средообразующий инструмент градостроительства / Л.С. Назарова // Academia. Архитектура и строительство. 2017. - № 4. - С. 125-129.

11. Бочаров, Ю.П. Стратегия тесной политики / Ю.П. Бочаров, Э. Сиренко // Коммерсантъ Власть. - № 10 (964) от 12.03.2013. - С. 24-26.

12. М-нов, А. Садово-Триумфальная площадь / А. М-нов // Строительство Москвы. - 1933. - № 7. - С. 20-22.

13. Верховному суду отложили переезд // Коммерсантъ. - № 56 от 03.04.2017. - С. 5.

14. Колганов, Г. Судебный квартал в Санкт-Петербурге превратится в парк [Электронный ресурс] / Г. Колганов // Коммерсантъ FM. 24.04.2019 [сайт]. - Режим доступа: https:// www.kommersant.ru/doc/3954242 (дата обращения 02.06.2019).

15. Шадрина, Т. Правительство согласовало переезд ряда министерств в «Москва-Сити» [Электронный ресурс] / Т. Шадрина // RG.RU, 04.01.2019 [сайт]. - Режим доступа: https:// rg.ru/2019/01/04/reg-cfo/pravitelstvo-soglasovalo-pereezd-riadaministerstv-v-moskva-siti.html (дата обращения 02.06.2019).

16. Бочаров, Ю.П. Центры власти в пространстве Москвы / Ю.П. Бочаров, Э.А. Сиренко // Архитектура в истории русской культуры. Вып. 4. Власть и творчество. - М. : Эра, 1999. - 192 с. - С. 54-60.

\section{References}

1. Bonch-Bruevich V.D. Pereezd Sovetskogo pravitel'stva iz Petrograda v Moskvu : (Po lichnym vospominaniyam) [Moving the Soviet government from Petrograd to Moscow: (According to personal memories)]. Moscow, Zhizn' i znanie Publ., 1926, 19 p. - (Biblioteka dokumentov, zapisok $i$ vospominanii : Kn. 11).

2. Konstitutsiya (Osnovnoi zakon) Soyuza Sovetskikh Sotsialisticheskikh Respublik. Utverzhdena Chrezvychainym VIII s"ezdom Sovetov Soyuza SSR 5 dekabrya 1936 goda [The Constitution (Basic Law) of the Union of Soviet Socialist Republics. Approved by the Emergency VIII with the "ride of the Soviets of the USSR on December 5, 1936]. Moscow, OGIZ Publ., 1937, $36 \mathrm{p}$.

3. Borozinets Yu.0. Istoriya sudebnoi sistemy Rossii epokhi SSSR 1917-1930-kh gg. [The history of the judicial system of Russia of the era of the USSR 1917-1930-ies]. Innovatsionnaya nauka [Innovative science], 2015, no. 7, pp. 64-67.

4. Osnovnye napravleniya gradostroitel'nogo razvitiya Moskvy i Moskovskoi oblasti na period do $2010 \mathrm{~g}$. [The main directions of urban development in Moscow and the Moscow region for the period up to 2010]. Moscow, Moskomarkhitektura, NIiPI Genplana Moskvy Publ., 1993, 95 p.

5. 0 General'nom plane goroda Moskvy: zakon goroda Moskvy № 17 ot 05.05.2010 [On the General Plan of the City of Moscow: Law of the City of Moscow No. 17 of 05/05/2010]. Vestnik Mera i Pravitel'stva Moskvy [Bulletin of the Mayor and the Government of Moscow], 03.06.2010, Spetsvypusk № 1, Vol. 1, 2, 3, St. 2.3, 3.3.

6. Bocharov Yu.P. Obshchestvennye prostranstva Moskvy v usloviyakh stanovleniya grazhdanskogo obshchestva [Public spaces of Moscow in the conditions of the formation of a civil society] Academia. Arkhitektura i stroitel'stvo [Academia. Architecture and construction], 2012, no. 2, pp. 101-105.

7. Putin vstupil v dolzhnost' prezidenta. Sravnivaem chetyre inauguratsii [Elektronnyi resurs] [Putin took office as president. Compare four inaugurations]. WVS. Russkaya sluzhba. 7.05.2018 [sait].URL: https://www.bbc.com/russian/news-44027663 (Accessed 25.06.2019).

8. Konchenkov S.M. Protsessual'nye kharakteristiki gradostroitel'nogo konflikta [Procedural characteristics of urban conflict]. Arkhitekton: izvestiya vuzov [Arkhitekton: News of universities], 2018, no. 3, pp. 1-12. ISSN 1990-4126

9. Tkachenko S.B. Odin vek moskovskogo gradostroitel'stva. Kn. 1. Moskva sotsialisticheskaya [One century of Moscow urban planning. Book. 1. Moscow is socialist]. Moscow, Ulei Publ, 2018, 312 p.

10. Nazarova L.S. Mechty o Manezhnoi ploshchadi: podzemnoe prostranstvo kak sredoobrazuyushchii instrument gradostroitel'stva [Dreams of Manege Square: underground space as an environment-forming tool for urban planning]. 
Academia. Arkhitektura i stroitel'stvo [Academia. Architecture and construction], 2017, no. 4, pp. 125-129.

11. Bocharov Yu.P. Strategiya tesnoi politiki [Close policy strategy]. Kommersant "Vlast'", no. 10 (964) of 12.03.2013, pp. 24-26.

12. M-nov A. Sadovo-Triumfal'naya ploshchad' [SadovoTriumfal'naya square]. Stroitel'stvo Moskvy [Construction of Moscow], 1933, no. 7, pp. 20-22.

13. Verkhovnomu sudu otlozhili pereezd [Supreme Court postponed the move]. Kommersant, no. 56 of 03/04/2017, P. 5.

14. Kolganov G. Sudebnyi kvartal v Sankt-Peterburge prevratitsya $v$ park [Elektronnyi resurs] [Judicial quarter in St. Petersburg will turn into a park]. Kommersant FM. 24.04.2019 [sait]. URL: https://www.kommersant.ru/doc/3954242 (Accessed 02.06.2019).

15. Shadrina T. Pravitel'stvo soglasovalo pereezd ryada ministerstv v «Moskva-Siti» [The government agreed on the relocation of a number of ministries in the "Moscow-City"]. RG.RU, 04.01.2019 [sait].URL: https://rg.ru/2019/01/04/ reg-cfo/pravitelstvo-soglasovalo-pereezd-riada-ministerstvv-moskva-siti.html (Accessed 02.06.2019).

16. Bocharov Yu.P. Tsentry vlasti v prostranstve Moskvy [Power centers in the space of Moscow]. Arkhitektura $v$ istorii russkoi kul'tury. Vyp. 4. Vlast' i tvorchestvo [Architecture in the history of Russian culture. Issue 4. Power and creativity]. Moscow, Era Publ., 1999, 192 p., pp. 54-60.

Бочаров Юрий Петрович (Москва). Доктор архитектуры, профессор, академик РААСН. Главный научный сотрудник ЦНИИП Минстроя России (Москва, пр. Вернадского, 29. ЦНИИП Минстроя России). Эл.почта: albocharova28@gmail.com.

Ткаченко Сергей Борисович (Москва). Кандидат архитектуры, член-корреспондент РАХ. Профессор МАРХИ (Москва, ул. Рождественка, 11/4. МАРХИ). Эл.почта: sbt@sbtkachenko.ru.

Bocharov Yuri Petrovich (Moscow). Doctor of Architecture, Professor, Academician of RAACS. Chief Researcher of the Central Institute for Research and Design of the Ministry of Construction and Housing and Communal Services of the Russian Federation (29 Vernadskogo avenue, Moscow, 119331. TsNIIP Minstroy of Russia). E-mail: albocharova28@gmail.com.

Tkachenko Sergey Borisovich (Moscow). Candidate of Architecture, Corresponding Member of the RAS. Professor of the Moscow Institute of Architecture (11/4 Rozhdestvenka st, Moscow, 107031. MARCHI). E-mail: sbt@sbtkachenko.ru. 